\title{
Przestrzenie oraz obiekty komunikacji pasażerskiej Wrocławia w kształtowaniu wydarzeń kulturalnych i społecznych miasta
}

\author{
Wojciech Jabłoński \\ e-mail: wojciech.jablonski@pwr.edu.pl \\ Zakład Konstrukcji i Budownictwa Ogólnego, Wydział Architektury, Politechnika Wrocławska \\ ul. Bolestawa Prusa 53/55, 50-317 Wroctaw
}

Adres do korespondencji:

Konopnica 16a, 21-030 Motycz

\begin{abstract}
Streszczenie: Przestrzenie oraz obiekty komunikacji publicznej, w szczególności dalekobieżnej, mają znaczący wpływ na odbiór miasta - jako miejsca pierwszego i ostatniego fizycznego kontaktu odbiorcy z miastem. Dworce, porty, stacje pasażerskie ze względu na intensywną wymianę użytkowników to również miejsca wymiany kultury, emocji, stając się tym samym przestrzeniami interakcji społecznych. Niniejsza praca przedstawia wybrane przestrzenie i obiekty komunikacji publicznej Wrocławia obejmujące różne rodzaje podróży - od międzymiastowej, przez regionalną, po lokalną wskazujące na rolę tych obiektów w kształtowaniu wizerunku miasta w świetle wydarzeń kulturalnych czy widowiskowych. Przestrzenie publiczne oraz obiekty komunikacji publicznej we Wrocławiu stanowią przykład w zakresie obsługi podróżnych, reprezentacyjności oraz budowaniu obrazu kulturowego i społecznego miasta.
\end{abstract}

Słowa kluczowe: Wrocław, komunikacja pasażerska, wydarzenia kulturalne

\section{Wstęp}

Bardzo ważnym czynnikiem wpływającym na odbiór miasta są jego obiekty komunikacji publicznej zarówno dalekobieżnej, rozumianej przez dworce i porty lotnicze, jak i obiekty komunikacji miejskiej, takie jak stacje przesiadkowe i ważne węzły komunikacyjne w morfologii miasta. O ile obiekty obsługujące ruch wewnątrzmiejski stanowią o wygodzie i czytelności lokalnego transportu zbiorowego, to obiekty komunikacji pasażerskiej dalekobieżnej są wizytówką miasta, jako pierwszy i ostatni fizyczny kontakt odbiorców z miastem odbierany nie tylko wzrokowo przez szybę środka lokomocji. Przestrzenie w i wokół obiektów komunikacji pasażerskiej budują pierwsze wrażenie dotyczące miasta, wpływając tym samym na jego odbiór i dziejących się w nim wydarzeń oraz utrwalają wspomnienie dotyczące wizyty, niezależnie od jej celu. Warunkuje to konieczność nie tylko właściwych rozwiązań funkcjonalnych, w tym komunikacyjnych i informacyjnych, ale również estetycznych i wizualnych wskazujących na prestiż i charakterystykę miasta (Wrocławia w 2016 roku jako Europejskiej Stolicy Kultury o bogatej historii).

Ponadto komunikacja zbiorowa sprzyja rozwojowi kontaktów społecznych, w której różni użytkownicy mają wspólny cel/środek - miejsce docelowe/podróż. Przez to obiekty komunikacji zbiorowej stanowią przestrzeń, w której następuje intensywna wymiana oraz konfrontacja obyczajów, a w przypadku większych miast nawet kultur. W ten sposób poza oczywistymi funkcjami transportu pasażerskiego oraz systemu informacji, dworce, stacje, czy też porty lotnicze stają się również obiektami komunikacji społecznej, dla której tłem jest podróż czy cel podróży, np. miasto czy wydarzenie kulturalne lub kulturowe. Przestrzenie takie wymagają specjalnego potraktowania - nie tylko jako miejsca w czytelny sposób spełniającego wymagania dotyczące bezpiecznej i sprawnej podróży, ale również miejsca, gdzie w oczekiwaniu na środek lokomocji człowiek zaspokaja potrzeby 
społecznych interakcji czy to sposób aktywny w relacjach interpersonalnych czy też bierny - jako obserwator teatru życia, a w przypadku Wrocławia w 2016 roku jako obserwator życia miasta - Europejskiej Stolicy Kultury.

Bardzo często przestrzenie publiczne, zarówno dośrodkowe ${ }^{1}$ jak i otwarte ${ }^{2}$ obiektów komunikacji pasażerskiej traktowane są jako miejsca transferowe, których jedynym celem jest umożliwienie dalszej podróży przyjezdnym. Interpretacja przestrzeni wyłącznie w ten sposób prowadzi do powstawania mało atrakcyjnych miejsc, których użytkowanie sprowadza się do krótkiej chwili obejmującej tylko zmianę środka lokomocji z formy dalekobieżnej na regionalną lub lokalną i regionalnej na lokalną. Następuje przez to sprzężenie zwrotne - nieatrakcyjne miejsce nie zachęca użytkownika do zatrzymania się, a przez to pozornie nie istnieje potrzeba ani możliwość realizacji innego celu danej przestrzeni publicznej, a to prowadzi do zaniedbania i braku zainteresowania danym obszarem jako zniechęcającym do użytkowania. Ze względu na położenie obiektów komunikacji pasażerskiej naziemnej, najczęściej w bliskim sąsiedztwie lub w centrum miasta, interpretacja ta powoduje degradację cennych terenów nie tylko tych transferowych, ale też sąsiednich - jako mało atrakcyjnych pod inwestycje. Ponadto przestrzenie te, obejmujące zarówno tereny wokół obiektów komunikacji pasażerskiej, jak i same obiekty mają potencjał ze względu na swoją lokalizację i ilość użytkowników, żeby pełnić rolę także rekreacyjną czy kształtującą świadomość społeczną czy kulturalną, a także określać tożsamość miasta.

\section{Wrocław - Dworzec Główny}

Transport kolejowy w Polsce stanowi najczęściej wybierany rodzaj transportu pasażerskiego. Pomimo zmniejszenia się popularności w latach 90. XX wieku wynikających z pojawieniem się na rynku prywatnego sektora transportu autobusowego (nazywanego Busami, ze względu na rodzaj środka lokomocji - mikrobusów), kolej wybrało 277,4 miliona osób w roku 2015, czyli o prawie 9 milionów więcej niż w 2014 roku. Dla porównania transport samochodowy wybrało 416,5 miliona pasażerów, o 16 milionów mniej niż w 2014 roku [1]. Duży transfer użytkowników wskazuje na atrakcyjność dworca ${ }^{3}$ pod funkcje dodatkowe, zarówno komercyjne, informacyjne, jak i społeczne oraz kulturalne.

Wybudowany w latach 1855-1857 według projektu Wilhelma Grapowa wrocławski Dworzec Główny początkowo znajdował się w południowej części Wrocławia, jednak w wyniku rozwoju urbanistycznego miasta w kierunku południowym "przybliżył” się do centrum. Wyniesienie pod koniec XIX wieku torów kolejowych ponad poziom terenu na estakadę usunęło tą morfologiczną przeszkodę dla rozwoju Wrocławia. Wzniesiony w stylu angielskiego neogotyku budynek recepcyjny doskonale harmonizuje ze stalową konstrukcją hali peronowej. W okresie przebudowy w latach 1899-1905 stacja kolejowa została rozbudowana: zwiększoną ilość peronów przesunięto w kierunku południowym, wyniesiono je nad poziom terenu na estakadę oraz przykryto nową halą. W miejscu dawnej hali peronowej wprowadzono hol dworcowy w poziomie torów, a budynek recepcyjny przearanżowano na sale restauracyjne, wprowadzając układ tarasów funkcjonalnych względem posadzki nowego holu [4].

W latach 2010-2012 dworzec wraz z placem przed dworcem przeszedł gruntowną rewitalizację, której autorem jest warszawska pracownia architektoniczna Grupa 5. Jednoprzestrzenny hall główny z wypiętrzeniem w formie tarasu, jako strefy wejściowej do lokali usługowych, tworzą czytelny układ funkcjonalny uzupełniony o strefę administracyjno-biurową w poddaszu dostępną z dachu nad holem dworcowym [6]. Podesty te w sposób czytelny, ale nieinwazyjny dzielą przestrzeń na dwie części - komunikacyjną oraz usługową. W ten sposób można również wydzielić hall główny jako przestrzeń publiczną w myśl Ustawy o planowaniu i zagospodarowaniu przestrzennym [6] jako ogólno dostępna, sprzyjająca kontaktom społecznym oraz realizująca potrzeby użytkowników [7, s. 52] o charakterze dośrodkowym, dopełnioną strefą pół-publiczną - lokali gastronomicznych i usługowych. Integracja tych przestrzeni wskazuje na kształtowanie się dworca jako miejsca nie tylko publicznego, ale i społecznego, uzupełnionego funkcją kulturalną w formie otwartej galerii - tablic w przestrzeni holu, ukazujących różne dzieła, np. fotografii artystycznej, czy też wydzielonych pomieszczeń - Art Main Station by

1 Dośrodkowa przestrzeń publiczna - wielofunkcyjna przestrzeń wewnętrzna imitująca przestrzeń zewnętrzną; przestrzeń publiczna zamknięta w zwartej strukturze [8, s. 9,17, 68-69].

2 Otwarta przestrzeń publiczna - przestrzeń niezawierająca się w budowli [8, s. 129].

3 Wrocławski Dworzec Główny posiada kategorię odprawy podróżnych A (powyżej 2 mln osób) [2], 5,6 mln pasażerów rocznie [3]. 
Mia w zachodniej części obiektu. Przestrzeń holu głównego to również potencjalne miejsce do aktywności kulturalnej innej niż sztuki wizualne. Przykładami tego typu wydarzeń może być „Flashmob Frozen Wrocław Nowy Główny" [9, s. 52], który odbył się 16 grudnia 2012 roku czy koncert muzyki klasycznej Orkiestry Kameralnej Leopoldinum [10].

Zachowanie dużej ilości detalu architektonicznego, stalowej konstrukcji oraz zastosowanie drewna jako materiału wykończeniowego budują pozytywny w odbiorze charakter dworca jako obiektu reprezentacyjnego oraz kreują element tożsamości miasta wskazując tym samym na długą historię Wrocławia i jego główne cechy. Neogotycki styl w połączeniu z współczesnymi rozwiązaniami architektoniczno-budowlanymi zawierają w sobie pewną esencję Wrocławia - jego historii, sięgającej czasów średniowiecza, w tym licznych obiektów gotyckich, a także współczesnej, nieco zagubionej, ale na nowo zbudowanej tożsamości miasta. Podróżny poza podstawowymi w przypadku obiektów transportu pasażerskiego potrzebami komunikacji i informacji ma możliwość realizacji pozostałych potrzeb - fizjologicznych oraz bezpieczeństwa dzięki czytelnym rozwiązaniom funkcjonalnym. Bezpośredni wpływ na poczucie bezpieczeństwa podróżnych ma prosty podział funkcjonalny i kompozycyjny. Główna oś obiektu przebiegająca pod kątem prostym względem osi holu głównego łączy poprzez tunel pod peronami plac dworcowy z ulicą Suchą, a dalej z dworcem autobusowym. Szerokość tunelu umożliwia spokojne i bezpieczne poruszanie się w pośpiesznym środowisku podróży, w którym każde zatrzymanie się może powodować niebezpieczne sytuacje zagrażające zdrowiu przez przestoje w strumieniu ruchu pieszych [6, s. 57]. Dodatkowe funkcje gastronomiczne i handlowe oraz automaty w przestrzeni tunelu zlokalizowane są we wnękach, nie wymagając tym samym strefy wejściowej w świetle samego przejścia.

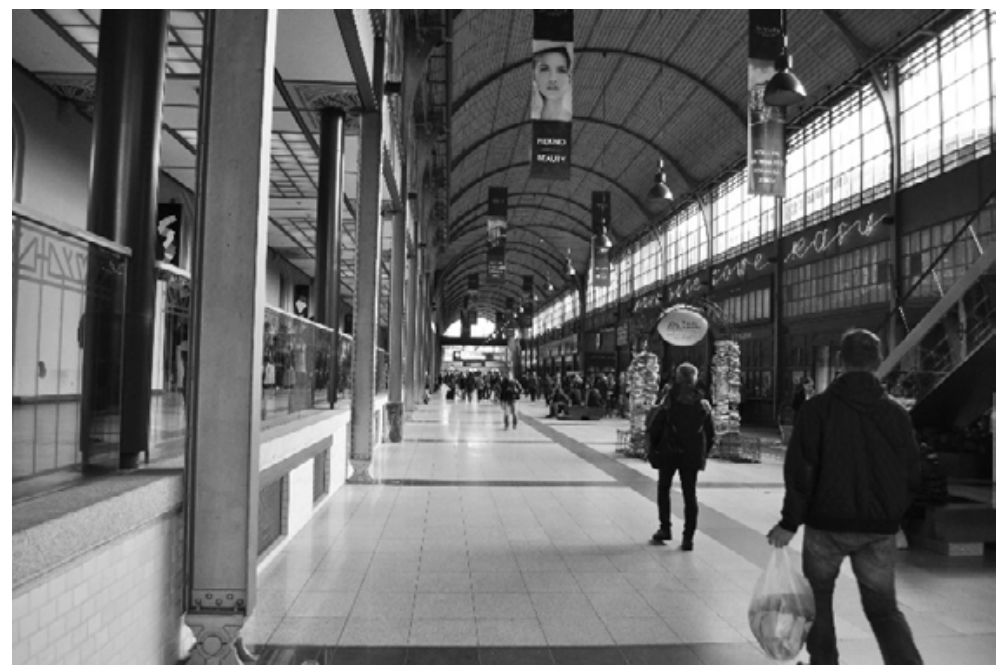

Ryc. 1. Dworzec Wrocław Główny, hol dworcowy, lokalizacja komercyjnych lokali usługowych na tarasach - dawnych peronach; stalowa konstrukcja hali harmonizuje ze neogotyckim stylem architektonicznym budynku; pojedyncze elementy wskazujące na funkcje kulturalne (tu instalacja z książek wskazująca na wypożyczalnię książek na podróż), fot. W. Jabłoński, październik 2016 r.

\section{Plac dworcowy}

Jednym z elementów kształtujących wizerunek miasta jest plac dworcowy, który pełni rolę przejściową między miastem a dworcem. W tym kontekście przestrzeń ta musi pełnić nie tylko funkcję komunikacyjną, ale również reprezentacyjną wymagającą specjalnego potraktowania - jako wizytówki, sprawnego węzła komunikacji miejskiej, a ze względu na swoje położenie blisko centrum miasta także społeczno-kulturalną.

Początkowo, pełniąc rolę reprezentacyjno-komunikacyjną, obsadzony był wyspami zieleni z podjazdem dla dorożek, jednak wraz z rozwojem cywilizacyjnym, a przede wszystkim środków transportu motoryzacyjnego, funkcja komunikacyjna zaczęła dominować nad jej reprezentacyjnym charakterem. Przed gruntowną modernizacją dworca oraz placu dworcowego, większą część przestrzeni przydworcowej stanowił parking dla samochodów osobowych i podjazdy dla taksówek, powodując tym samym degradację terenu oraz sąsiedztwa.

Przez plac dworcowy przebiegają dwie przelotowe ulice: Piłsudskiego oraz Peronowa. Jednak ze względu na swoje skrajne położenie (odsunięcie ul. Piłsudskiego na północną część placu od dworca oraz Peronową 
na zachodnią) nie zaburzają one funkcjonalności placu pod kątem komunikacji pieszej i jej bezpieczeństwa. Charakterystyczna dla dworców przelotowych geometria placu dworcowego domknięta jest tkanką architektoniczną: od południa budynkiem dworca, północy zabudową mieszkaniowo-usługową, od zachodu budynkiem biurowym, od wschodu budynkiem urzędu pocztowego. Istotnym elementem składającym się na funkcjonalne i kompozycyjne domknięcie placu jest oddany do użytku w 2014 roku Silver Tower zaprojektowana przez Maćków Pracownia Projektowa [11]. Obiekt poza lokalami usługowo-handlowymi w swoim programie posiada 3-gwiadkowy hotel oraz biura. W obrębie przestrzeni publicznej, rozumianej przez domknięcie tkanką architektoniczną, znajdują się najważniejsze obiekty komunikacji lokalnej miejskiej - przystanki tramwajowe i autobusowe, postój taksówek. Wyżej wymienione elementy wraz z dworcem kolejowym i dworcem autobusowym przy ulicy Suchej, po południowej stronie estakady kolejowej, tworzą węzeł integracyjny ${ }^{4}$, mający istotny wpływ na funkcjonowanie i rangę przestrzeni, wskazując na pozytywne skutki rewitalizacji dworca i placu dworcowego.

Jednym $z$ istotnych elementów zagospodarowania placu są tarasy przeznaczone między innymi pod lokale gastronomiczne, podniesione względem powierzchni placu o $105 \mathrm{~cm}$, a usytuowane pomiędzy ryzalitami elewacji frontowej. Dostępność z placu lokali usługowych pozwala na wprowadzenie dodatkowej funkcji poza komunikacyjną, podnosząc tym samym znaczenie samego placu, nie tylko jako węzła komunikacyjnego. Dostępne z zewnątrz lokale gastronomiczne tworzą enklawy półpubliczne, uzupełniając plac o funkcję gastronomii oraz handlową nie tylko dla podróżnych, ale i mieszkańców miasta. Tarasy wraz ze schodami prowadzącymi na nie oraz miejscami do siedzenia w formie podwyższonych stopni mogą stanowić scenę i widownię dla wydarzeń kulturalnych lub teatru życia codziennego.

Na placu można wyróżnić różnicę wysokości pomiędzy jego północną krawędzią (stykiem z jezdnią przy ulicy Piłsudzkiego) a południową (wejściem do budynku dworca). Plac nachylony jest w kierunku północnym o około 2,2\%, a różnica wysokości wynosi około $130 \mathrm{~cm}$. Poza koniecznością zniwelowania rzędnych terenu pomiędzy ulicą Piłsudskiego a wejściem, różnica ta ułatwia podróżnym orientację w przestrzeni - zapewniając lepszy wgląd na plac, a co za tym idzie łatwiejsze odczytanie oraz wyszukiwanie poszczególnych funkcji na przykład przystanku tramwajowego.

Bardzo ważnym elementem budującym plac, są zielone wyspy w formie pagórków. Stanowią one doskonałe miejsce do wypoczynku lub oczekiwania na środek lokomocji. Ponadto w swoim układzie wytyczają wnęki, pozwalające na izolację w otwartej przestrzeni placu, tworząc tym samym układ enklaw spokoju w układzie komunikacyjnym placu. Ponadto wyspy te wraz ze szpalerami drzew, platanów klonolistnych w północnej części placu, wskazują na genius loci miasta [5].

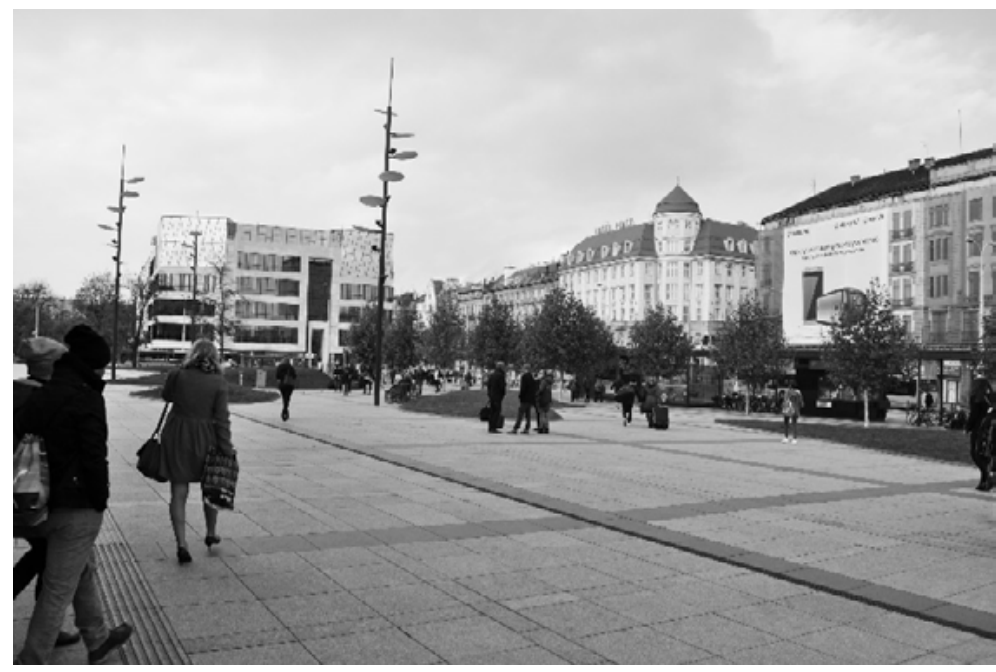

Ryc. 2. Plac dworcowy, lekkie nachylenie (około 2\%) placu wspomaga orientację w przestrzeni podróży, a wraz z tarasami między ryzalitami scenę życia miasta, fot. W. Jabłoński, październik 2016 r.

4 Węzeł integracyjny - węzeł komunikacyjny/przesiadkowy - zespół przestrzeni i obiektów wiążąca różne systemy transportu uzupełnione o funkcje dodatkowe, takie jak handel, gastronomia, hotele, itp. [12, s. 140-141] 
Plac dworcowy pełni podstawowe funkcje:

- reprezentacyjną jako urbanistyczny element między miastem a dworcem,

- komunikacji, mającą na celu zapewnienie bezpiecznej zmiany środka transportu,

- społeczną, mającą na celu umożliwienie relacji społecznych, kontaktu oraz zaspokojenia podstawowych potrzeb człowieka,

- komunikacji kołowej obejmującej parking „kiss and ride" ${ }^{5}$ i postój taksówek we wschodniej części placu,

- obsługi lokali gastronomicznych jako uliczki pod placem wzdłuż elewacji dworca,

- kulturalną/kulturową mającą na celu zapewnienie możliwości rozwoju potrzeb wyższych - rozwoju kulturalnego, tożsamości społecznej.

Przykładem realizacji funkcji społecznej może być Marsz Patriotów jako wydarzenie umacniające więzi społeczne i budujące tożsamość kulturową ludności nie tylko lokalnej. Plac dworcowy w roku 2016 roku był początkiem trasy przemarszu [13] jako miejsce w bliskim sąsiedztwie dworca, pozwalające na zgromadzenie się dużej ilości osób przede wszystkim przyjezdnych.

Przykładem wydarzeń kulturalnych na placu jest instalacja multimedialna "Luneta”, zorganizowana w ramach Europejskiej Stolicy Kultury 2016 oraz wpisująca się w program „Europejskie Sąsiedztwo”. Projekt opierał się na połączeniu multimedialnym dwóch przestrzeni podróży - placu dworcowego we Wrocławiu oraz Friedrichstrasse w Berlinie. Instalacja polegała na utworzeniu kopuły, w której wnętrzu, za pomocą ekranów i kamer istniało audiowizualne połączenie z identyczną kopułą w Berlinie [14].
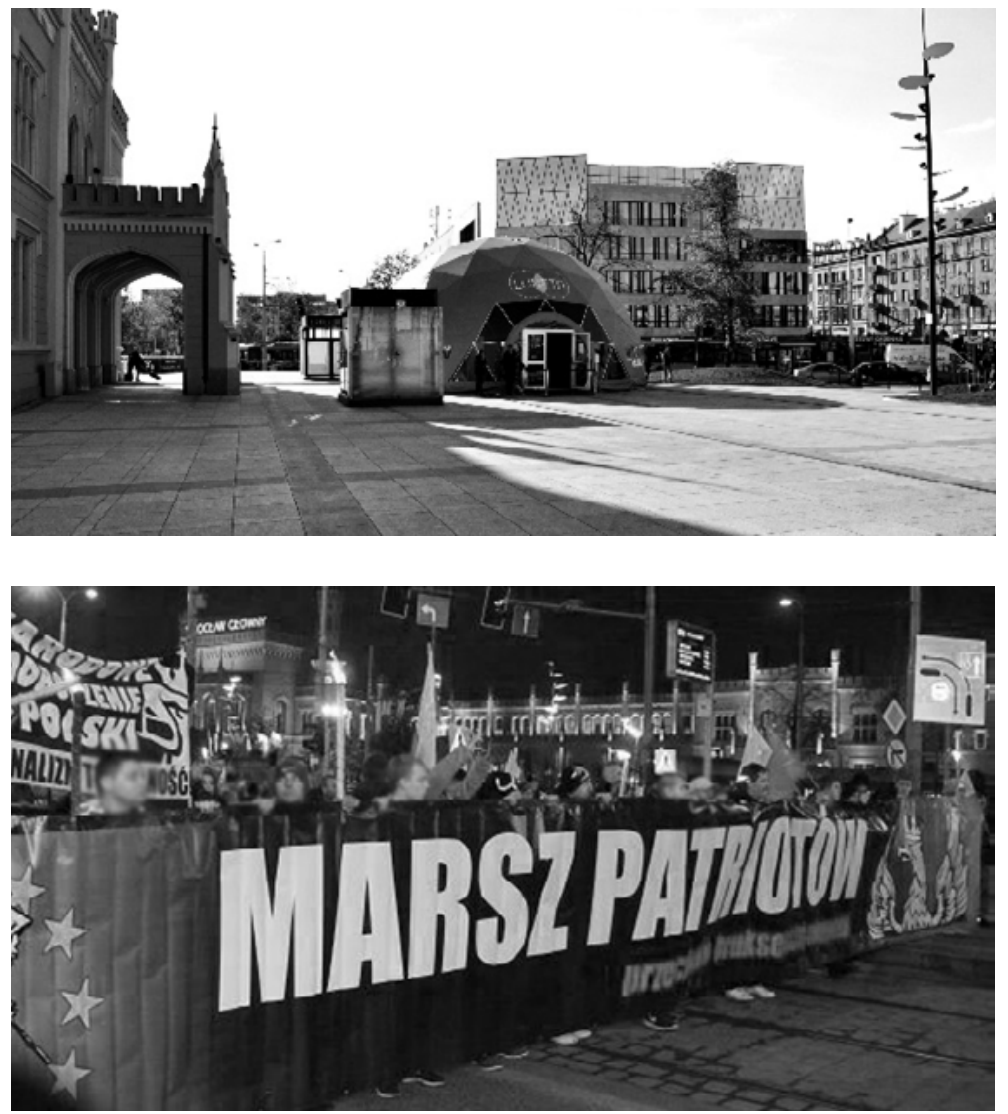

Ryc. 3. Po lewej: instalacja multimedialna Luneta na placu przed dworcem Wrocław Główny, źródło: http://miejscawewroclawiu.pl/?p=423, dostęp: 14.10 .2016 r.

Ryc. 4. VII Marsz Patriotów 2016, plac przed dworcem jako miejsce rozpoczęcia przemarszu, źródło: http://serwis21. blogspot.com/2016/11/to-my-to-my-polacy-vii-marsz-patriotow.html, dostęp: 10.12.2016 r. 


\section{Dworzec autobusowy}

Wrocławski dworzec autobusowy POLBUS w dniu 8 kwietnia 2015 roku został zamknięty i przeniesiony na tymczasową płytę znajdującą się w bliskim sąsiedztwie przy ulicy Suchej, która ze względu na budowę nowego, wielofunkcjonalnego obiektu będzie pełniła swoją funkcję do października 2017 roku, kiedy to do użytku ma być oddany nowy dworzec autobusowy wraz z galerią handlową [15]. Nowy obiekt budowany w kwartale ulic Suchej, Borowskiej, Dyrekcyjnej i Joanitów wraz z kompleksem placu dworcowego i funkcji mu towarzyszących oraz dworcem kolejowym wejdzie w skład zintegrowanego węzła komunikacyjnego jako miejsca o nadrzędnej funkcji komunikacji uzupełnionego komercyjnymi funkcjami handlu, gastronomii i innych usług.

Budowa nowego obiektu odpowiada trendom we współczesnej polityce samorządowej miast, w której budowa zintegrowanych centrów przesiadkowych współfinansowana jest przez prywatnych, komercyjnych inwestorów. Forma ta stanowi odciążenie budżetu miasta z niezbędnych do poniesienia kosztów, jakimi są realizacje inwestycji celu publicznego, w tym przypadku dworca autobusowego. Ponadto formuła budowy tego typu obiektów uzupełnia tkankę urbanistyczną przy dworcach autobusowych, które pomimo swojego znaczenia w funkcjonowaniu miasta, zwłaszcza egzogennego, są mało atrakcyjne jako otwarte przestrzenie publiczne, rozumiane głównie przez płytę manewrową. W przypadku nowego dworca autobusowego we Wrocławiu problem ten został rozwiązany przez sprowadzenie płyty manewrowej na kondygnacje podziemne, uwalniając tym samym atrakcyjne z punktu widzenia komercyjnego kondygnacje parteru.

Rozwiązania tego typu niosą za sobą jednak wiele zagrożeń, których większość wynika z problemów zdefiniowania nowej przestrzeni. Bardzo często zostaje zatarta granica pomiędzy poszczególnymi strefami, gdzie funkcja handlu wnika w funkcję transportu, marginalizując tym samym podstawową rolę dworca. Tym samym tego typu obiekty stają się symbolem obecnego społeczeństwa skazanego na pośpiech i nastawionego na konsumpcję dóbr. W tym kontekście dworzec autobusowy jako węzeł komunikacyjny i jego forma architektoniczna podążają za obrazem kulturowym współczesnego społeczeństwa i kultury masowej, a jednocześnie poprzez istotną funkcję użyteczności publicznej, transportu pasażerskiego, w sposób pośredni kształtują społeczeństwo i jego nastawienie kulturowe.

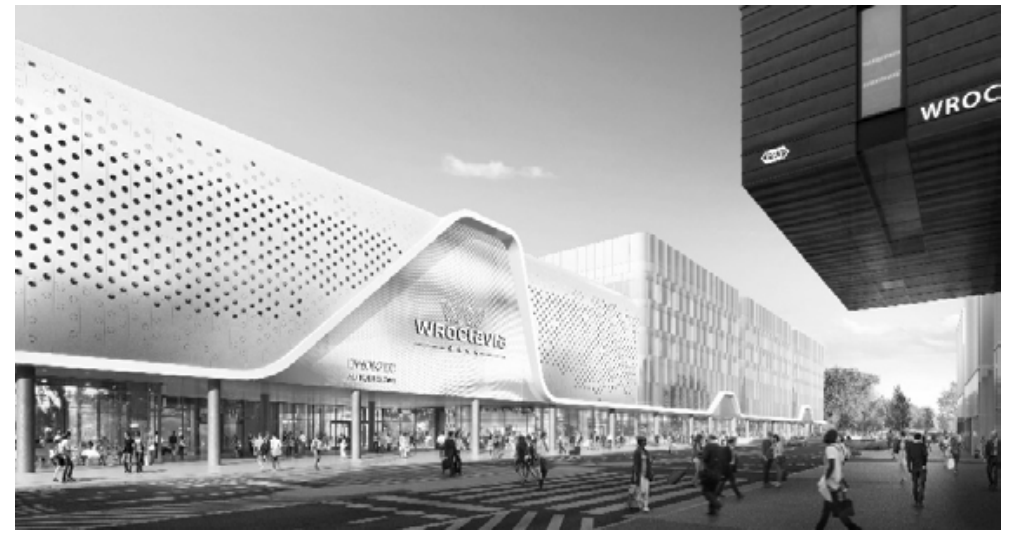

Ryc. 5. Wroclavia, wielofunkcjonalny obiekt z dworcem autobusowym, holem w przyziemiu i płytami manewrowymi w kondygnacjach podziemnych, wizualizacja, źródło: http://wroclavia.pl/galeria (dostęp: 10.12 .2016 r.)

\section{Węzeł przesiadkowy - Wrocław Stadion}

W kształtowaniu obrazu kulturowego i społecznego miasta bardzo ważną rolę spełnia jego stadion miejski jako arena wydarzeń sportowych i kulturalnych. Wybudowany w 2011 roku obiekt pełni funkcję stadionu dla największego klubu piłkarskiego we Wrocławiu WKS Śląsk Wrocław, na którym odbywają się przede wszystkim spotkania ligowe oraz pucharowe o randze krajowej, ale też spotkania międzynarodowe. Obiekt ten to również miejsce masowych wydarzeń takich jak koncerty, pokazy motoryzacyjne czy inne widowiska. Ponadto pod trybunami dla 45 tysięcy osób znajdują się sale wielofunkcyjne, mogące być miejscem dla różnego rodzaju 
konferencji, sympozjów czy bankietów [16]. W tym kontekście dla właściwego funkcjonowania tego obiektu położonego przy osiedlu Pilczyce niebywale ważne są połączenia komunikacyjne zarówno miejskie, jak i regionalne.

Przy stadionie, po jego południowej stronie, znajduje się duży węzeł komunikacyjny zaprojektowany przez pracownię projektową Maćków [17]. Obejmuje on drogę krajową numer 94, Autostradową Obwodnicę Wrocławia, przystanek tramwajowy w kierunku Leśnicy oraz linię kolejową. Ilość różnych rodzajów środków komunikacyjnych stanowiła wyzwanie dla bezpiecznej organizacji ruchu. W poziomie terenu usytuowano linię kolejową nad którą przebiegają równolegle na estakadach trakcja tramwajowa oraz ruch kołowy. W miejscu przecięcia się linii kolejowej z tramwajową utworzono podwójny przystanek, węzeł przesiadkowy pomiędzy różnymi rodzajami transportu, uzupełniony parkingiem typu „Park and Ride"6 W południowo-wschodniej części założenia. Jednym z istotniejszych elementów komunikacyjnych założenia jest utwardzony ciąg pieszy łączący węzeł przesiadkowy z stadionem. Ciąg ten rozszerza się w kierunku stadionu regulując tym samym przepływ widzów oraz ułatwiając kontrolę tłumu.
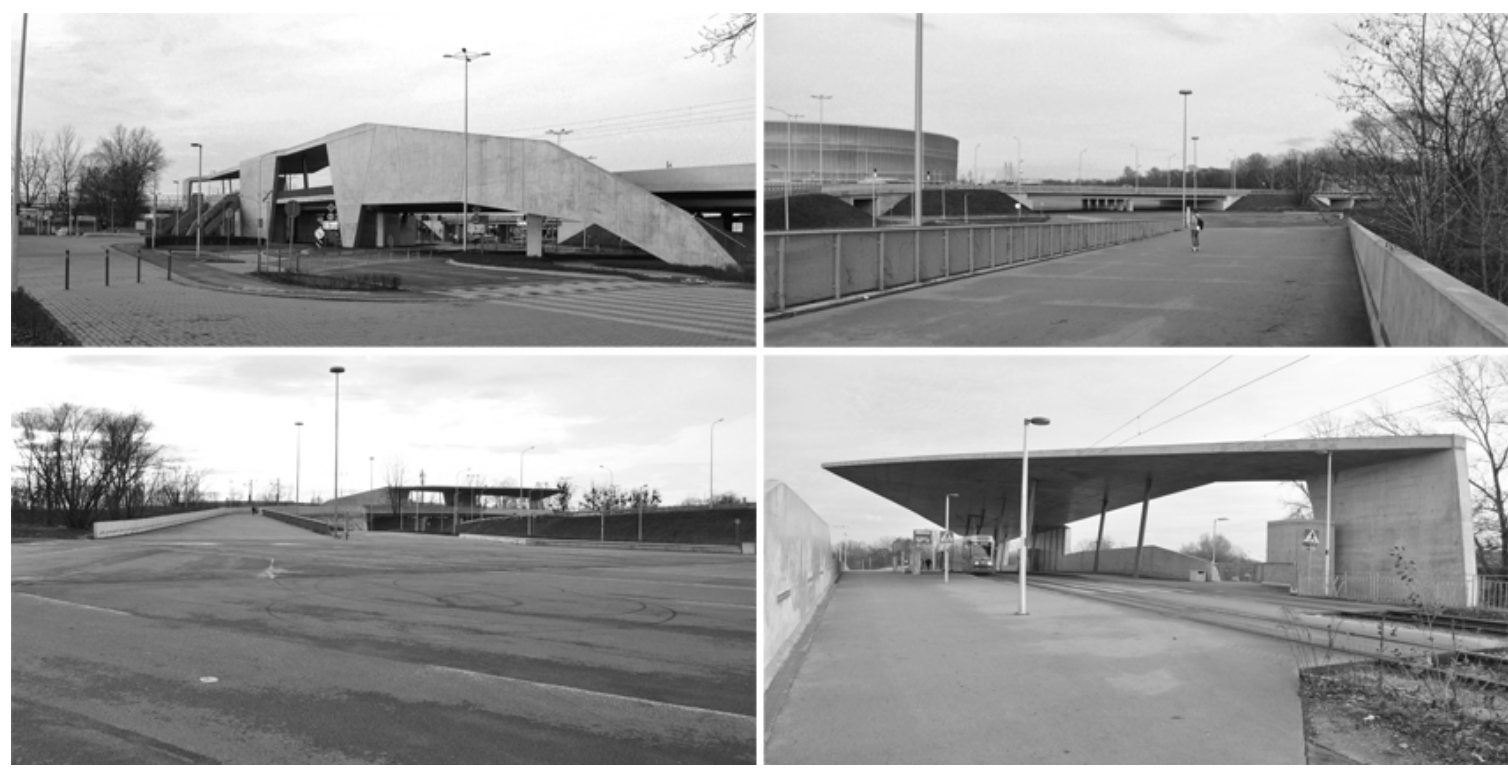

Ryc. 6. Węzeł przesiadkowy Wrocław Stadion, surowa architektura przestrzeni komunikacji; przestrzeń transferowa między przystankiem a stadionem wykorzystywana do rekreacji; dynamiczne zadaszenie o kształcie zbliżonym do trójkąta przykrywające głównie peron w kierunku centrum miasta, fot. W. Jabłoński, grudzień 2016 r.

Przystanki komunikacji zbiorowej znajdują się na dwóch poziomach. Na dolnym w poziomie terenu zlokalizowano przystanek kolejowy, częściowo przykryty estakadą oraz przystanek tramwajowy. Wraz z systemem „parkuj i jedź" przystanek ma potencjał stanowić nie tylko dogodne połączenie komunikacyjne w czasie wydarzeń na stadionie, ale również przy 34 połączeniach kolejowych na dobę jako dogodny system obsługujący miasto, a odciążający ruch miejski [19]. Górna część przykryta jest dynamicznym zadaszeniem w kształcie trapezu zbliżonym do trójkąta, którego dłuższy bok przylega do zewnętrznej krawędzi peronu tramwajowego w kierunku centrum miasta. Tym samym większa część zadaszeni przykrywa strefę przystanku o zwiększonym natężeniu pasażerów, podczas gdy drugi peron, o głównej funkcji wysiadania, przykrywa tylko fragment peronu.

Forma architektoniczna węzła przesiadkowego powstawała równolegle z stadionem miejskim. Brak kontekstu oraz skomplikowane układy komunikacyjne wpłynęły na realizację dynamicznej w formie surowej architektury, kojarzącej się z betonowym krajobrazem angielskiego brutalizmu. Wskazują w ten sposób na swoją podstawową funkcję komunikacji, która stanowi głównie środek do celu jakim jest widowisko na stadionie.

6 Parking "Park and ride” - parking typu „parkuj i jedź” to sytuowany na obrzeżach miasta parking dla samochodów osobowych, mający umożliwić użytkownikom pozostawienie samochodu oraz łatwą komunikację z centrum miasta za pomocą środków transportu publicznego w celu odciążenia ruchu kołowego z centrum. 
Zagospodarowanie terenu pomiędzy węzłem a stadionem wykorzystywane jest przez deskorolkarzy jako miejsce o wielu wartościach sprzyjających tej formie rekreacji. Szerokie połacie jednorodnej nawierzchni przy braku wydarzeń i aktywności na stadionie stanowią idealną przestrzeń odizolowaną od dużego natężenia ludzi, co bezpośrednio przekłada się na bezpieczeństwo i komfort zarówno samych deskorolkarzy, jak i osób postronnych, przypadkowych przechodniów. Pochylnie prowadzące na stadion oraz na przystanek tramwajowy pełnią rolę ramp zjazdowych o bezpiecznym nachyleniu, a formy małej architektury, takie jak monolityczne betonowe ławki, dodatkowych elementów do ćwiczeń. Jedną z podstawowych zalet tego miejsca jako przestrzeni dla tej formy rekreacji jest jego dostępność związana z lokalizacją węzła przesiadkowego, przez co jest atrakcyjne nie tylko dla lokalnych mieszkańców, ale łatwo dostępna niemal dla każdego mieszkańca Wrocławia i okolicznych miejscowości. Węzeł komunikacyjny wspomaga w tym wypadku aktywizację terenów otaczających, które przez większość czasu jest nieużytkowana. Można też stwierdzić, że przestrzenie dedykowane niemal wyłącznie wydarzeniom na stadionie oraz związane z transportem, mogą pełnić również funkcje rekreacyjne.

\section{Przystanki komunikacji miejskiej}

Publiczny transport miejski stanowi jeden z podstawowych elementów funkcjonowania miasta. W kontekście kształtowania, a przede wszystkim promowania wydarzeń kulturalnych czy społecznych pełnią przestrzenie publiczne obejmujące przystanki i stacje przesiadkowe komunikacji miejskiej. Ich rola nie ogranicza się jedynie do umożliwienia bezpiecznego użytkowania środku transportu oraz oczekiwania na niego. Ze względu na dużą ilość regularnych użytkowników oraz dostępność całodobową, miejsca te stają się doskonałym kanałem do przepływu informacji. W przypadku wydarzeń kulturalnych w mieście zewnętrzne kampanie reklamowe, mające zazwyczaj odmienny charakter od reklam komercyjnych, mają możliwość trafić do szerokiego grona odbiorców i wywołać odpowiednie uczucia, zaskoczenie, a także sprowokować do odpowiednich, zaplanowanych reakcji [18, s. 52, 53]. Ze względu na zakres lokalny ten nośnik informacji posiada ograniczenia terytorialne oraz czasowe, jednak w przypadku akcji jaką jest Europejska Stolica Kultury stanowi doskonałe źródło wiadomości o wydarzeniach w mieście.

W przypadku wydarzeń kulturalnych lub społecznych akcje promocyjne przybierają formy bardziej ekspresyjne, tym samym mocniej wpływając na uwagę użytkowników przestrzeni miejskiej. Przykładem wskazującym na prowokacyjny charakter reklamy wydarzeń na przystankach komunikacji miejskiej jest akcja promująca wydarzenie Sztuka \#tuiteraz, które odbyło się 18 września 2016 roku przed Infopunktem Barbara na ulicy Kazimierza Wielkiego w ramach Tygodnia Mobilności [19]. W ramach tej akcji na 19 przystankach we Wrocławiu ułożono trawniki wzbudzając tym samym zainteresowanie użytkowników komunikacji miejskiej, a przez swój niecodzienny charakter w sposób pośredni przez wymianę informacji w grupach społecznych, także osób nie korzystających z transportu miejskiego. Zielone trawniki wskazywały również na cechy promowanego wydarzenia, którym był piknik na fragmencie ulicy Kazimierza Wielkiego, której powierzchnia częściowo została pokryta właśnie trawnikiem [20].

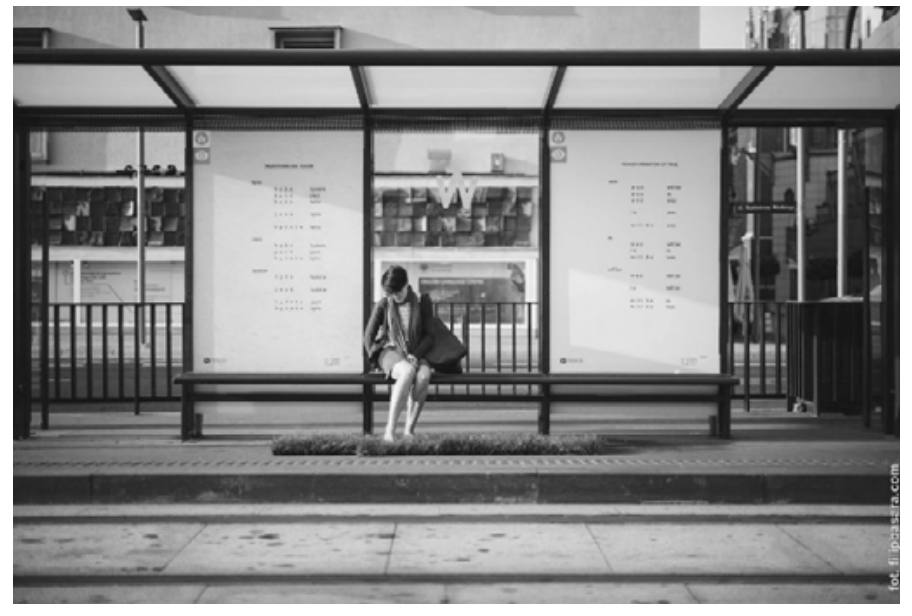

Ryc. 7. Po lewej: trawa na przystanku przy przejściu Świdnickim we Wrocławiu, jak również projekt Stanisław Dróżdż. Ścieżki tekstu na nośnikach reklamowych, 12.09.2016 r., fot. Filip Basara, źródło: http://wroclaw.eska.pl/newsy/trawa-na-wroclawskich-przystankach-to-zaproszenie-na-weekend-wideo-galeria/4419/1, dostęp: 28.01.2017 r. 


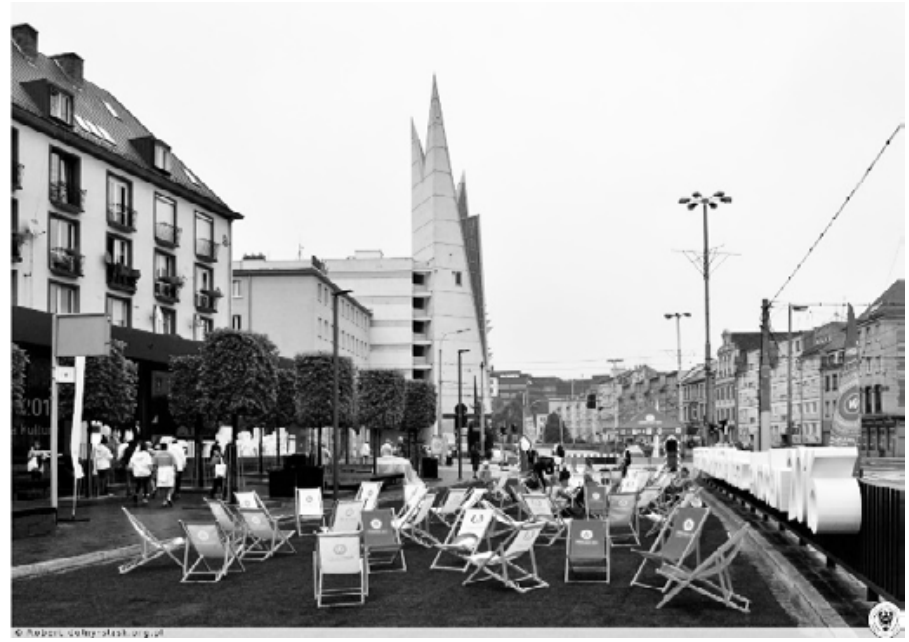

Ryc. 8. Po prawej: happening Sztuka \#tuiteraz, ul. Kaziemierza Wielkiego, $18.09 .2016 \mathrm{r}$. źródło: http://dolny-slask.org.pl/6265892,foto. html?idEntity=6265685, dostęp: 28.01.2017 r.

Przystanki komunikacji publicznej oprócz funkcji promującej poszczególne wydarzenia, pełnić mogą również stanowić nośnik dla projektów wizualnych - fotografii, plakatu, a także literackich jak w przypadku projektu Stanisław Dróżdż. Ścieżki tekstu. Przystanek w kontekście twórczości Stanisława Dróżdża, poezji konkretnej stanowiącej formę sztuki wizualnej, pomaga wyjść poezji poza ramy stronic [21]. W ramach projektu 5 września 2016 roku środki komunikacji miejskiej były wykorzystane jako element samego wydarzenia, tym samym przestrzeń publiczna wokół i sam tramwaj stały się formą przekazu sztuki.

\section{Podsumowanie}

Działania zapoczątkowane w 2008 roku na rzecz wydarzeń kulturalnych [22] znalazły swoje odzwierciedlenie w przygotowaniach przestrzeni publicznych oraz obiektów użyteczności publicznej w tym obiektów komunikacji pasażerskiej - jednego z podstawowych aspektów mających na celu obsługę dużych wydarzeń widowiskowych oraz samego życia miasta, jego kultury i społeczeństwa. Przedstawione w pracy obiekty wskazywały na potencjał miasta w 2011 roku $^{7}$ i jego zaplecze funkcjonalno-przestrzenne oraz komunikacyjne w kontekście wydarzeń kulturalnych i społecznych.

Na podstawie przedstawionych przykładów można wykazać, że założenia komunikacyjno-przestrzenne pełnią niebagatelną rolę w odbiorze miasta, jako miejsca reprezentacyjne oraz obsługujące miasto i region. W skali pojedynczego widowiska przez właściwe zaakcentowanie poszczególnych cech funkcjonalno-przestrzennych, w tym komunikacyjnych, estetycznych, czy obejmujących bezpieczeństwo użytkowania, wspomagają one w odbiorze wydarzeń w sposób bezpośredni lub pośredni. Przestrzenie te stanowią też doskonały środek promujący poszczególne wydarzenia kulturalne wpływając na szerokie grono odbiorców.

Ponadto ze względu na swoje położenie i ogólną dostępność nie tylko dla ludności lokalnej, przestrzenie publiczne obejmujące transport i ruch mogą również pełnić funkcje kulturotwórcze, rekreacyjne czy budujące tożsamość społeczeństwa. Tym samym wskazują na istotną rolę w kształtowaniu jakości przestrzeni publicznych przy obiektach komunikacji pasażerskiej jako miejsc nie tylko transferowych, ale mogących służyć również innym użytkownikom i celom. Właściwe zagospodarowanie i użytkowanie tych terenów podnosi wartości użytkowe nie tylko ich samych, ale i obszarów z nimi sąsiadujących.

Wrocławskie obiekty transportu publicznego wraz przestrzeniami obejmującymi ruch pasażerów, widzów i innych użytkowników, wskazują na charakterystykę miasta, która obejmuje jego trudną historię, przemiany społeczne, dynamiczny rozwój oraz wizerunek kulturowy. Wskazują one na elementy wartościowe z przeszłości miasta wplatające się w obecne trendy i wartości architektoniczne, kształtujące wizerunek Wrocławia nie tylko jako Europejskiej Stolicy Kultury 2016, ale też miasta służącego swojemu społeczeństwu. 


\section{Bibliografia}

[1] Główny Urząd Statystyczny, Przewozy ładunków i pasażerów w 2015 r., Warszawa, 2016 źródło: stat.gov.pl/obszary-tematyczne/transport-i-lacznosc/transport/przewozy-ladunkow-i-pasazerow-w-2015-roku,11,4.html (dostęp: 10.10 .2016 r.)

[2] pl.wikipedia.org/wiki/Wrocław_Główny (dostęp 12.10.2016 r.)

[3] pkp.wroclaw.pl/ (dostęp 12.10.2016 r.)

[4] Harasimowicz J., Atlas Architektury Wrocławia, tom I, Wrocław 1997

[5] http://www.grupa5.com.pl/projekty/modernizacje

[6] Ustawa z dnia 27 marca 2003 r. o planowaniu i zagospodarowaniu przestrzennym, Dz.U. 2003 nr 80 poz. 717

[7] Poliński J., Dworce we współczesnym transporcie kolejowym, [w:] Prace Instytutu Kolejnictwa, Zeszyt 150, 2016

[8] Lorens P., Gtówne typy i rodzaje wspótczesnych przestrzeni publicznych, [w:] Lorens P., Martyniuk-Pęczek J. (red.), Problemy ksztattowania przestrzeni publicznych, Gdańsk 2010

[9] Pięt A., Przestrzeń publiczna wewnątrz dworców kolejowych i w ich otoczeniu, [w:] Architektura, 3/ 2014

[10] http://wroclawnowyglowny.pl/aktualnosci/ponad-300-osob-na-koncercie-na-glownym (dostęp 28.10.2016 r.)

[11] www.mackow.pl/projects/silver-tower-kopia-3/ (dostęp 14.10.2016 r.)

[12] Ogrodnik D., Dworce i przystanki kolejowe a miejskie przestrzenie publiczne, [w:] Zeszyty Naukowe Politechniki Śląskiej, zeszyt 44, 2006

[13] www.wroclaw.pl/11-listopada-marsz-patriotow-mozliwe-utrudnienia-w-ruchu (dostęp 10.11.2016 r.)

[14] www.wroclaw.pl/esk-2016-luneta-zajrzyj-do-berlina-i-wroclawia (dostęp 14.10.2016 r.)

[15] http://www.wroclaw.pl/tymczasowy-dworzec-pks-wroclaw-od-8-kwietnia-mapa (dostęp 28.11.2016 r.)

[16] www.stadionwroclaw.pl (dostęp: 28.11.2016 r.)

[17] https://www.mackow.pl/projects/zintegrowany-wezel-przesiadkowy-wroclaw-stadion/ (dostęp: 28.11 .2016 r.)

[18] Mikosz J., Formy reklamy zewnętrznej, [w:] Kultura Media Teologia, zeszyt 33, 2010

[19] http://wroclaw.naszemiasto.pl/artykul/trawa-na-przystankach-we-wroclawiu-co-to-za-akcja-zdjecia,3854369,artgal,t,id,tm. html (dostęp: 28.01.2017 r.)

[20] http://www.wroclaw2016.pl/sztuka-tuiteraz-czyli-piknik-w-centrum-miasta-juz-w-niedziele (dostęp: 28.01 .2017 r.)

[21] http://www.sciezki-tekstu.pl/ (dostęp: 28.01.2017 r.)

[22] http://www.rozklad-pkp.pl/ (dostęp: 28.11.2016 r.)

[23] http://www.wroclaw2016.pl/o-esk (dostęp: 09.12.2016 r.)

\section{Ilustracje}

[1] Dworzec Wrocław Główny, hol dworcowy, lokalizacja komercyjnych lokali usługowych na tarasach - dawnych peronach; stalowa konstrukcja hali harmonizuje ze neogotyckim stylem architektonicznym budynku; pojedyncze elementy wskazujące na funkcje kulturalne (tu instalacja z książek wskazująca na wypożyczalnię książek na podróż), fot. W. Jabłoński, październik 2016 r.

[2] Plac dworcowy, lekkie nachylenie (około 2\%) placu wspomaga orientację w przestrzeni podróży, a wraz z tarasami między ryzalitami scenę życia miasta, fot. W. Jabłoński, październik 2016 r.

[3] Po lewej: instalacja multimedialna Luneta na placu przed dworcem Wrocław Główny, Źródło: http://miejscawewroclawiu.pl/?p=423, dostęp: 14.10 .2016 r.

[4] VII Marsz Patriotów 2016, plac przed dworcem jako miejsce rozpoczęcia przemarszu, Źródło: http://serwis21.blogspot. com/2016/11/to-my-to-my-polacy-vii-marsz-patriotow.html, dostęp: 10.12 .2016 r.

[5] Wroclavia, wielofunkcjonalny obiekt z dworcem autobusowym, holem w przyziemiu i płytami manewrowymi w kondygnacjach podziemnych, wizualizacja, Źródło: http://wroclavia.pl/galeria (dostęp: 10.12 .2016 r.)

[6] Węzeł przesiadkowy Wrocław Stadion, surowa architektura przestrzeni komunikacji; przestrzeń transferowa między przystankiem a stadionem wykorzystywana do rekreacji; dynamiczne zadaszenie o kształcie zbliżonym do trójkąta przykrywające głównie peron w kierunku centrum miasta, fot. W. Jabłoński, grudzień 2016 r.

[7] Trawa na przystanku przy przejściu Świdnickim we Wrocławiu, 12.09.2016 r., fot. Filip Basara, źródło: http://wroclaw.eska. $\mathrm{pl} /$ newsy/trawa-na-wroclawskich-przystankach-to-zaproszenie-na-weekend-wideo-galeria/4419/1, dostęp: $28.01 .2017 \mathrm{r}$.

[8] Happening Sztuka \#tuiteraz, ul. Kaziemierza Wielkiego, 18.09.2016 r. źródło: http://dolny-slask.org.pl/6265892,foto. html?idEntity=6265685, dostęp: 28.01.2017 r. 


\title{
Spaces and Buildings of Passenger Transport in Wrocław in the Context of Cultural and Social Events
}

\begin{abstract}
Public transport buildings and their spaces have a significant impact on the perception of the city, as they are the first and the last physical contact between visitor and the city. Railway stations, ports, passenger stations due to the intensive exchange of users are also spaces of exchange of culture and emotions, and thus social interactions. This work presents selected spaces and public transport buildings in Wrocław covering different types of travel - from intercity, regional, to local passenger's transport, which indicate the role of these spaces in shaping the image of the city in the context of cultural and entertainment events. The public spaces and public transport facilities in Wrocław are examples in terms of passenger service, representativeness and creation of the cultural and social image of the city.
\end{abstract}

Keywords: Wrocław, passenger transport, cultural events 